\title{
Intraorbital Meningioma
}

National Cancer Institute

\section{Source}

National Cancer Institute. Intraorbital Meningioma. NCI Thesaurus. Code C6778.

A meningioma that affects the intraorbital structures. 